\title{
LEAF INDUMENTUM TYPES IN POTENTILLA (ROSACEAE) AND RELATED GENERA IN IRAN
}

\author{
MARZIEH BEYGOM FAGHIR ${ }^{1}$, FARIDEH ATTAR ${ }^{1}$, ALI FARAZMAND ${ }^{2}$, \\ BARBARA ERTTER ${ }^{3}$, BENTE ERIKSEN ${ }^{4}$ \\ ${ }^{1}$ Central Herbarium of Tehran University, \\ School of Biology, University College of Science \\ P.O. Box: 14155-6455, Tehran, Iran \\ e-mail: marziehfaghir@yahoo.com \\ 2 University of Tehran, \\ Department of Cell \& Molecular Biology School of Biology, University College of Science \\ P.O. Box: 14155-6455, Tehran, Iran \\ ${ }^{3}$ University and Jepson Herbaria, University of California, Berkeley \\ California 94720-2465, USA \\ ${ }^{4}$ University of Göteborg, Department of Plant Environmental Sciences \\ Box 461, SE-405 30, Göteborg Sweden
}

(Received: December 5, 2009. Accepted: March 23, 2010)

\begin{abstract}
Indumentum types of the leaves in 31 species of Potentilla L. (Rosaceae) and four related genera, especially Tylosperma Botsch., Schistophyllidium (Juz. ex Fed.) Ikonn., Drymocallis Fourr. ex Rydb., and Sibbaldia L. from Iran were investigated. Indumentum ultrastructure was studied by scanning electron microscopy (SEM). SEM observation revealed three type classes based on leaf indumentum: 1) straight (appressed - erect); 2) straight-erect and crispate, and 3) crispate-floccose. The straight hair character (I type class) is widely distributed among all genera sampled and six sections of Potentilla. In contrast the crispate-floccose indumentum (III type class) is confined to all examined species of sections Speciosae and Pensylvanicae. While some sections especially Rectae (straight and straight - crispate hairs) and Terminales (straight - crispate and floccose - crispate) posses two indumentum type classes. The present survey shows that indumentum types are of systematic importance and may form good key characters for identification purposes.
\end{abstract}

KEY WORDS: Potentilla, Tylosperma, Schistophyllidium, Drymocallis, Sibbaldia, indumentum, ultrastructure, classification, Iran.

\section{INTRODUCTION}

The large, complex genus Potentilla L. (Rosaceae) consists of several hundred species, mostly herbaceous perennials distributed in arctic and temperate regions of the northern hemisphere. In Iran species of Potentilla occur mainly in the northern, northwestern and southern parts of the country, on alpine meadows, rocky places, riverbanks, lakes, streams, pastures and roadsides (Schiman-Czeika 1969; Khatamsaz 1993).

Schiman-Czeika's (1969) treatment of Potentilla, in the Flora Iranica reported 51 species of Potentilla arranged in 18 sections from Iran, Afghanistan, parts of western Pakistan, northern Iraq, Azerbaijan and Turkmenistan. Seven additional species of Potentilla were mentioned as "Incertae et incomplete notae". Duchesnea Smith., Comarum L. and Sibbaldia L. were treated as separate genera. Subsequent changes to Schiman-Czeika's treatment, as compiled by Ertter and Attar (2007), resulted in 58 species of Potentilla L., three species of Drymocallis Fourr. ex Rydb., two species of Tylosperma Botsch., and one species each of Farinopsis Chrtek and Soják., Schistophyllidium (Juz. ex Fed.) Ikonn., Dasiphora Raf., Duchesnea J. E. Smith. and Sibbaldia L. in the area covered by Flora Iranica (Schiman-Czeika 1969).

The nomenclatural implications and adjustments for Europe, North America, and Iran have been addressed respectively by Kurtto and Eriksson (2003), Ertter (2007) and Ertter and Attar (2007).

Most species of Potentilla possess different types of indumentum on the leaves as well as other parts. Indumentum types were used as a key character in classification 
(e.g., Juzepczuk 1941; Li et al. 2003; Eriksen and Yurtsev 1999; Soják 1986, 1989, 2004, 2007).

Eriksen and Yurtsev (1999) also developed a consistent terminology for ultrastructure-defined indumentum types in Potentilla, modified from Radford et al. (1974) and Stearn (1983) and comparable to that used by Soják (e.g., 1986, 1989, 2004, 2007). Detailed illustrations of petiole indumentum are provided in several papers in Soják's series of "Notes on Potentilla" (e.g., Soják 1986: 155; 1989: 757; 2007: 319, 321).

The current paper supplements previous studies as a systematic survey of indumentum ultrastructure of species of Potentilla and segregate genera in Iran, in order to obtain comparative information useful for understanding the relationships among species of Potentilla. The resultant data should serve to provide strong evidence for evaluating the grouping and classification of the genus, especially given the diversity of Potentilla in Iran.

\section{MATERIALS AND METHODS}

We studied the indumentum of upper and lower leaf surfaces of 35 species from 10 sections of Potentilla and four related genera in Iran representing over half of the species and most of the genera and sections currently known in the area covered by Flora Iranica (Schiman-Czeika 1969; Ertter and Attar 2007).

Materials were either newly collected from different parts of Iran from 2005 to 2007 or obtained from Tehran University Herbarium (TUH) and other Iranian herbaria. The voucher specimen of each newly collected species was

TABLE 1. Grouping of species based on types of indumentum; * indicates presence of glandular trichomes.

\begin{tabular}{|c|c|c|c|}
\hline Species & Section & \multicolumn{2}{|c|}{ Group } \\
\hline 1 -Potentilla adenophylla* & Aureae & \multirow{18}{*}{$\begin{array}{c}\text { Sparse } \\
\text { to moderately dense } \\
\text { (pilose, sericeous, strigose, hirsute) }\end{array}$} & \multirow{24}{*}{ I } \\
\hline 2 - Potentilla micrantha $*$ & Micranthae & & \\
\hline 3 - Potentilla argyroloma & Persicae & & \\
\hline $4-$ Potentilla aucheriana $*$ & Persicae & & \\
\hline 5 -Potentilla bungei* & Persicae & & \\
\hline 6 - Potentilla nuda & Persicae & & \\
\hline 7 - Potentilla kurdica & Persicae & & \\
\hline 8 - Potentilla persica & Persicae & & \\
\hline 9 - Potentilla reptans & Potentilla & & \\
\hline $10-$ Potentilla hirta & Rectae & & \\
\hline 11 - Potentilla iranica & Rectae & & \\
\hline $13-$ Potentilla recta $*$ & Rectae & & \\
\hline 14 - Potentilla szovitsii & Rectae & & \\
\hline 15 - Potentilla supina $*$ & Rivales & & \\
\hline 16 -Drymocallis poteriifolia $*$ & Drymocallis & & \\
\hline 17 -Drymocallis rupestris * & Drymocallis & & \\
\hline 18 - Schistophyllidium bifurcum * & Schistophyllidium & & \\
\hline 19 - Sibbaldia parviflora & Sibbaldia & & \\
\hline 20 - Potentilla pannosa & Persicae & \multirow{4}{*}{ Dense (hirtellous) } & \\
\hline 21 - Potentilla petraea & Persicae & & \\
\hline 22 - Potentilla porphyrantha & Persicae & & \\
\hline 23 - Tylosperma lignosa & Tylosperma & & \\
\hline 25 - Potentilla elvendensis & Persicae & \multirow[t]{2}{*}{ Flexuose (villose) } & \\
\hline 26 - Potentilla mallota & Persicae & & \\
\hline 27 - Potentilla adscharica $*$ & Rectae & \multirow{3}{*}{ Straight-erect and crispate } & \multirow{3}{*}{$\begin{array}{c}\text { II } \\
\text { Straight-erect and crispate }\end{array}$} \\
\hline $28-$ Potentilla radiata $*$ & Rectae & & \\
\hline 29 - Potentilla inclinata & Terminales & & \\
\hline 30 - Potentilla anserina & Pentaphylloides & \multirow{6}{*}{ Floccose and crispate } & \multirow{6}{*}{$\begin{array}{c}\text { III } \\
\text { Floccose-Crispate (Woolly) }\end{array}$} \\
\hline 31 - Potentilla argentea & Terminales & & \\
\hline 32 - Potentilla meyeri & Terminales & & \\
\hline 33 - Potentilla hololeuca & Pensylvanicae & & \\
\hline 34 - Potentilla polyschista & Pensylvanicae & & \\
\hline 35 - Potentilla speciosa & Speciosae & & \\
\hline
\end{tabular}


deposited in Tehran University Herbarium (TUH). Flora Iranica (Schiman-Czeika 1969) was the primary reference for identifications, with some nomenclatural updates as per Ertter and Attar (2007). Species sampled are listed in Appendix 1 by genus and section, with nomenclatural authorship provided for all species, sections, and genera.

Specimens were prepared for scanning electron microscopy (SEM) using protocols derived from Nation (1983), Slížová et al. (2003) and Adams et al. (1987). Leaves (or a portion of them) were washed in boiling water-detergent and fixed overnight in glutaraldehyde $2.5 \%$ (prepared in Sorensen's phosphate buffer of $0.1 \%$ ). The tissue was then washed in three changes of buffer (five minutes each) and one change of water (five minutes). Dehydration was carried out using a series of ethanol washes $(70 \%, 85 \%, 95 \%$ and $100 \%)$. At this stage, tissues were immersed in hexamethyldisilazane for 5 minutes and then air-dried at room temperature. Dried materials were mounted on SEM stubs by double-sided adhesive tape of silver paint and finally coated with gold in a sputter coater. Scanning electron microscopy was carried out using a Vega Tescan Razi instrument. The terminology of indu- mentum ultra structures and types follows mainly that of Eriksen and Yurtsev (1999).

\section{RESULTS}

Scanning electron microscopy revealed three types of leaf indumentum: 1) straight hairs (appressed - erect); 2) straight - crispate, and 3) crispate-floccose. Distribution of species by indumentum type classes is shown in Table 1 .

Type I. The straight hair characters are widely distributed among all genera sampled and six sections of Potentilla, especially Schistophyllidium (Schi. bifurcum (L.) Ikonn.), Sibbaldia (S. parviflora Willd.), Drymocallis (D. poteriifolia (Boiss.) Soják., D. rupestris (L.) Soják.), Tylosperma (T. lignosa (Willd.) Botsch.), and Potentilla sect. Rectae ( $P$. hirta L., P. iranica (Rech.f.) SchimanCzeika, $P$. pedata Nestl., $P$. recta L., $P$. szovitsii Th.Wolf.), $P$. sect. Persicae ( $P$. argyroloma Boiss. and Hohen., $P$. aucheriana Th.Wolf., P. bungei Boiss., P. elvendensis Boiss., $P$. kurdica Boiss. and Hohen., P. mallota Boiss., $P$.
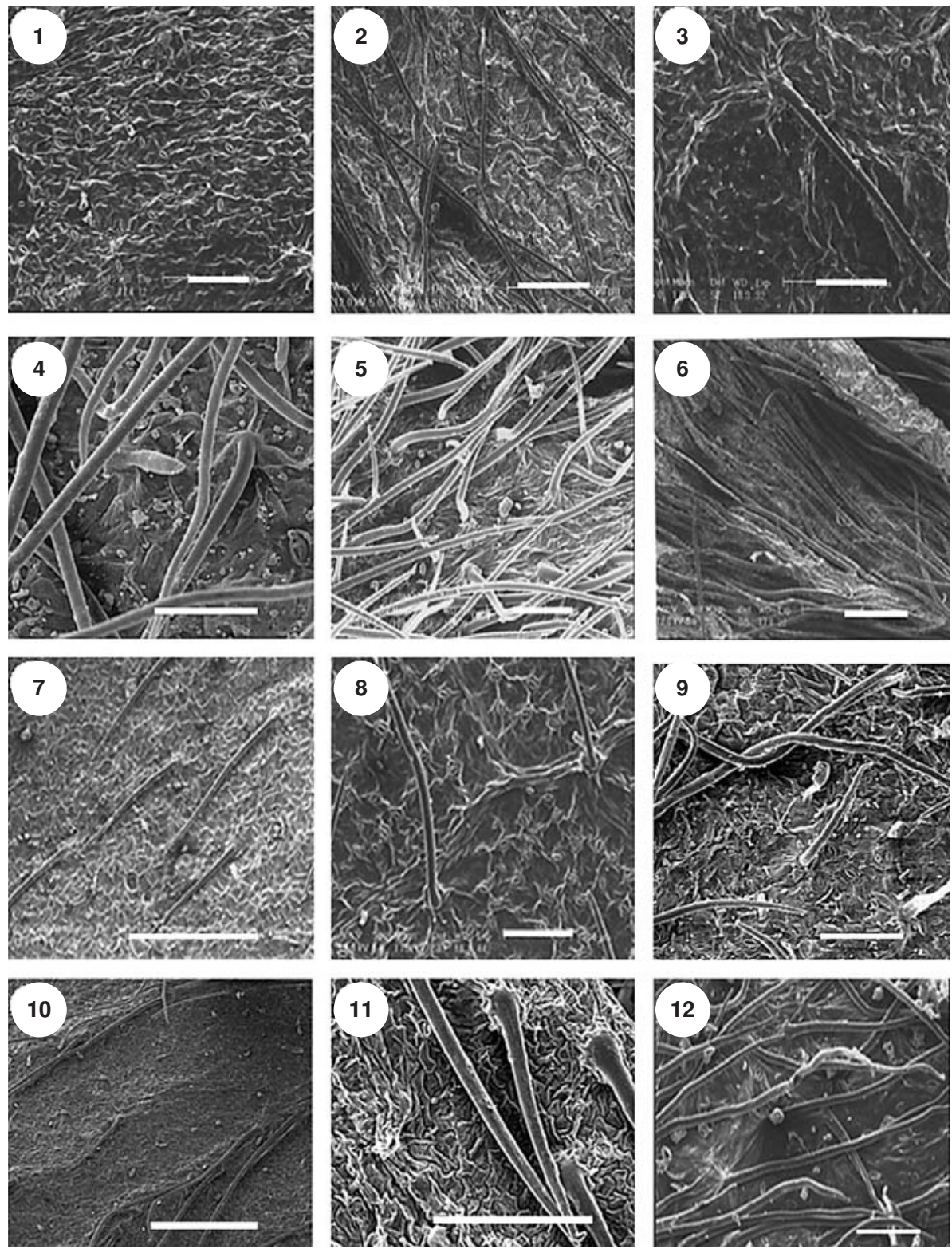
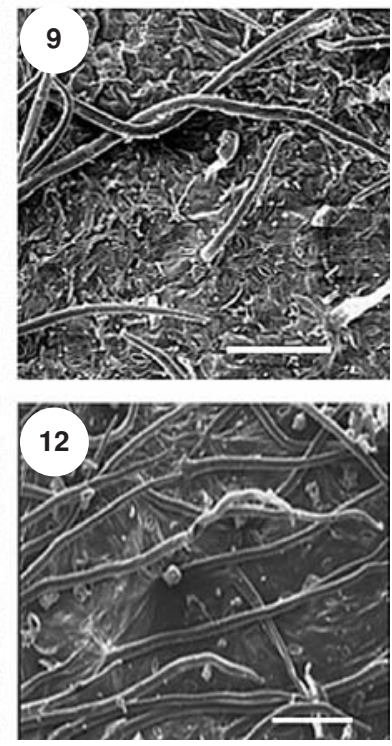

Figs 1-12. Scanning electron micrographs of straight hairs on leaves of Potentilla (lower surface). Type class I, straight indumentum category A) Fig. 1. Potentilla adenophylla, Figs 2 and 3. Potentilla micrantha; Fig. 4. Potentilla argyroloma; Fig. 5. Potentilla bungei; Fig. 6. Potentilla nuda; Fig. 7. Potentilla persica; Fig. 8. Potentilla reptans; Fig. 9. Potentilla iranica; Figs $\mathbf{1 0}$ and $\mathbf{1 1 .}$ Potentilla recta; Fig. 12. Potentilla supina. Figs $1-3,5-9$ and $12-$ scale bar $=100 \mu \mathrm{m}$; Fig. 4 - scale bar $=50 \mu \mathrm{m}$; Fig. $10-$ scale bar $=500 \mu \mathrm{m}$; Fig. $11-$ scale bar $=200 \mu \mathrm{m}$. 
nuda Boiss., P. pannosa Boiss. and Hausskn., P. persica Boiss. and Hausskn., P. petraea Willd., P. porphyrantha Juz.), P. sect. Potentilla (P. reptans L.), P. sect. Micranthae ( $P$. micrantha Ramond ex DC.), $P$. sect. Rivales ( $P$. supina L.) and $P$. sect. Aureae (P. crantzii (Crantz) Beck ex Fritsch., $P$. adenophylla Boiss. and Hohen.). Type I is further divided into three categories:

Type I category ${ }_{\text {A) }}$ Sparse to moderately dense (pilose, sericeous, strigose, hirsute)

Type I category ${ }_{\text {B) }}$ very dense (hirtellous)

Type I category ${ }_{\mathrm{C}}$ exceptionally long and flexuous (villose).

Category ${ }_{\text {A) }}$ indumentum, is present in following samples: Potentilla adenophylla Boiss. and Hohen (Fig. 1) of $P$. sect. Aureae, $P$. micrantha Ramond ex DC.), (Figs 2 and 3 ) of $P$. sect. Micranthea, P.argyroloma Boiss. and Hohen. (Fig. 4), P. aucheriana Th.Wolf., P. bungei Boiss. (Fig. 5), P. kurdica Boiss. and Hohen., P. nuda Boiss. (Fig. 6), $P$. persica Boiss. and Hausskn. (Fig. 7) of $P$. sect. persicae, $P$. reptans L. (Fig. 8) of $P$. sect. Potentilla, P. hirta L., $P$. iranica (Rech.f.) Schiman-Czeika. (Fig. 9), P. pedata
Nestl., P. recta L. (Figs 10 and 11) of P. sect. Rectae, $P$. supina L. (Fig. 12) of $P$. sect. Rivales and three related genera: Schistophyllidium (Schi. bifurcum (L.) Ikonn. (Fig. 13), Sibbaldia (S. parviflora Willd.) (Fig. 14) and Drymocallis (D. poteriifolia (Boiss.) Soják. (Figs 30 and 32) D. rupestris (L.) Soják.) (Figs 33 and 34).

Category $_{\text {B) }}$ indumentum is observed in Potentilla pannosa Boiss. and Hausskn. (Fig. 15), P. petraea Willd. (Fig. 16), $P$. porphyrantha Juz. of $P$. sect. Persicea and one related genus: Tylosperma (T. lignosa (Willd.) Botsch.) (Fig. 17).

Category ${ }_{\mathrm{C})}$ indumentum is found in the following sections and species: Potentilla crantzii (Crantz) Beck ex Fritsch. (Fig. 18) of $P$. sect. Aureae and P. elvendensis Boiss. (Fig. 19 ) and $P$. mallota Boiss. (Fig. 20) of $P$. sect. Persicae.

The ultrastructural study revealed that straight erect hairs are unicellular, mostly with smooth surfaces. No obviously verrucose hairs were noted in the species studied. The erect hairs that are placed on basal cells project more or less perpendicularly from the leaf surface. In certain species, e.g. $P$. bungei Boiss. the basal cell is long with sessile small tubercles (Fig. 5).
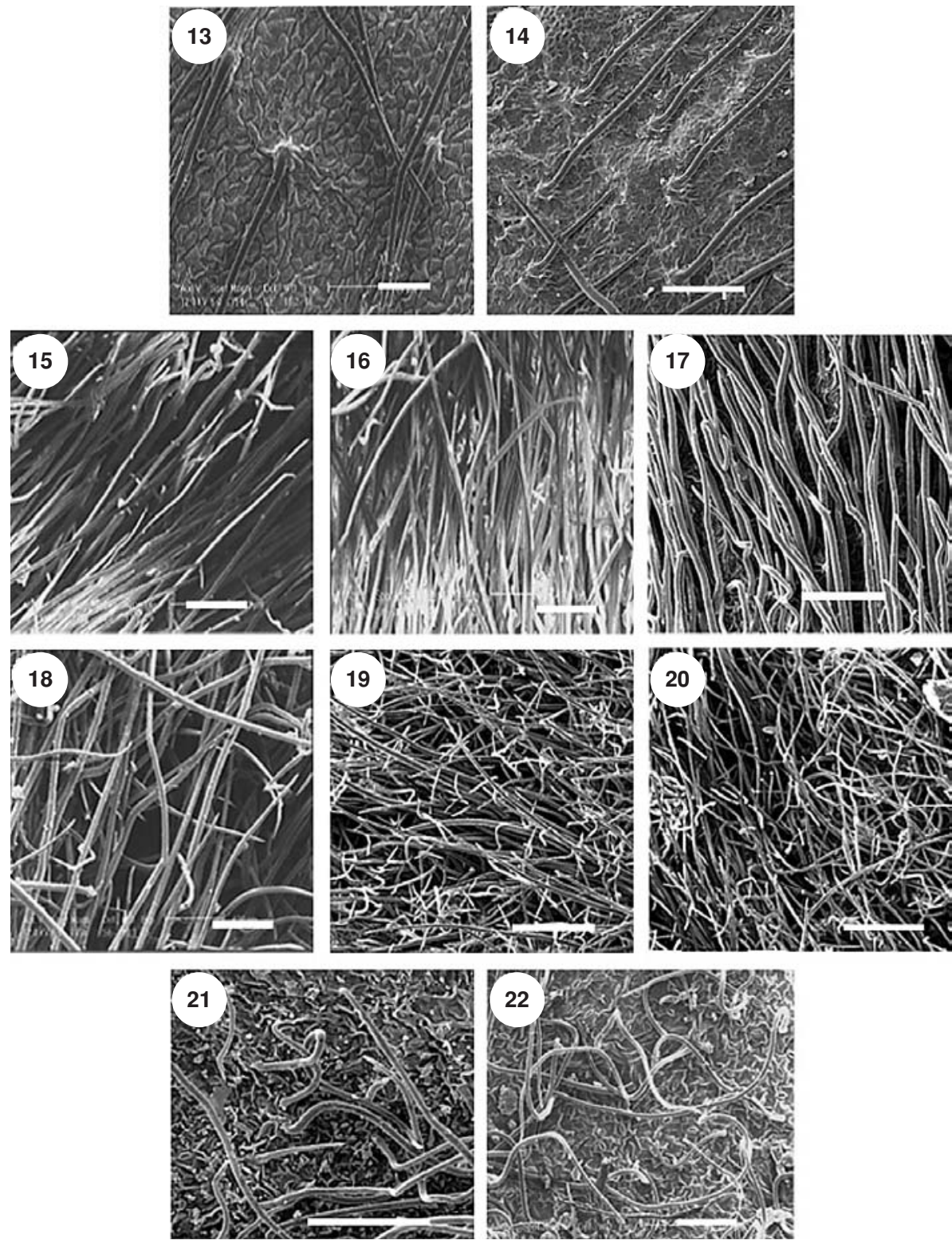

Figs 13-22. Straight indumentums. Type class I category A). Fig. 13. Schistophyllidium bifurcum; Fig. 14. Sibbaldia parviflora. Type class I category B) very dense (hirtellous); Fig. 15. Potentilla pannosa; Fig. 16. Potentilla petraea; Fig. 17. Tylosperma lignosa. Type class I category C) exceptionally long and flexuous Fig. 18. Potentilla crantzii; Fig. 19. Potentilla elvendensis; Fig. 20. Potentilla mallota. Type class II, straight-erect and straight-crispate indumentums; Fig. 21. Potentilla adscharica; Fig. 22. Potentilla radiata.

Figs $13,15-22-$ scale bar $=100 \mu$ m; Fig. 14 - scale bar $=200 \mu \mathrm{m}$. 
Type II. This type consists of taxa with both straighterect and crispate hairs and includes some representatives of $P$. sect. Rectae (e.g. P. adscharica Sommier \& Levier ex R.Keller, $P$. radiata (Th.Wolf) Juz.) and $P$. sect. Terminales (e.g. $P$. inclinata Vill.).

Type III. This type includes floccose - crispate (Figs 23 and 24) hairs (giving rise to a woolly indumentum) and is found in $P$. sect. Pentaphylloides ( $P$. anserina L.), $P$. sect. Terminales ( $P$. argentea $\mathrm{L}$. and $P$. meyeri Boiss.), $P$. sect. Pensylvanicae ( $P$. hololeuca Boiss. ex Lehm., P. polyschista Boiss.) and P. sect. Speciosae (P. speciosa Willd.).

In $P$. anserina L. a mixture of loosely floccose and crispate hairs is present especially on the lower surface of the leaves (Fig. 25). In most taxa crispate hairs were mixed with either straight or floccose hairs. In $P$. argentea L. (Fig. 26) and P. speciosa Willd. (Fig. 29) highly compact floccose indumentum with sparse crispate hairs formed tufted wool on the lower or either sides of the leaves.

Glandular trichomes commonly occur on the leaves of Potentilla either as the dominating pubescence or intermingled with other hair types. The small size indumentums often are covered with dense wool and are hardly distinguishable.

Glandular trichomes in studied species of Potentilla consist of a one to two celled stalk and single head (e.g. $P$. aucheriana Th.Wolf., $P$. recta L., $P$. micrantha Ramond ex DC. and $P$. bungei Boiss.) (Figs 35-38). While in genus Drymocallis (D. poteriffolia (Boiss.) Soják. and $D$. rupestris (L.) Soják.) (Figs 30-34) longer glandular hairs composed of a three to five celled stalk and single head are observed.

\section{DISCUSSION}

The present survey showed that majority of species from different sections of Potentilla (Micranthae, Persicae, Potentilla, Rivales) and four related genera (Drymocallis, Schistophyllidium, Sibbaldia, Tylosperma) which include all the type I taxa, lack crispate - floccose-hairs (woolly indumentum). In contrast species of Potentilla sect. Pentaphylloides, $P$. sect. Pensylvanicae and $P$. sect. Speciosae have only crispate-floccose indumentum (woolly indumentum) (type III). However some sections possess two indumentum type classes e.g. $P$. sect. Rectae (straight and straight - crispate hairs, I and II type classes) and $P$. sect. Terminales (straight - crispate and floccose - crispate, II and III type classes).

Eriksen and Yurtsev (1999) used straight and woolly indumenta (composed of crispate - floccose hairs) as key characters for grouping of species of section Niveae.

Types I and III identified in the present survey correspond to the straight and crispate - floccose hair types coined by Eriksen and Yurtsev (1999).

There are some morphological affinities between Iranian taxa with wooly indumentum and those of $P$. sect. Multifidae, $P$. sect. Niveae and $P$. sect. Argenteae of former subgenus Hypargyrium (Juzepchuk 1941).

In certain genera, especially Drymocallis (Figs 30-34) gland types are of systematic importance and informative (Sojak 2004; Ertter 2007). In the species of Iran, presence or absence of glands along with indumentum types plays important role in classification of Potentilla sect. Rectae and its species especially $P$. hirta L., $P$ iranica (Rech.f.)
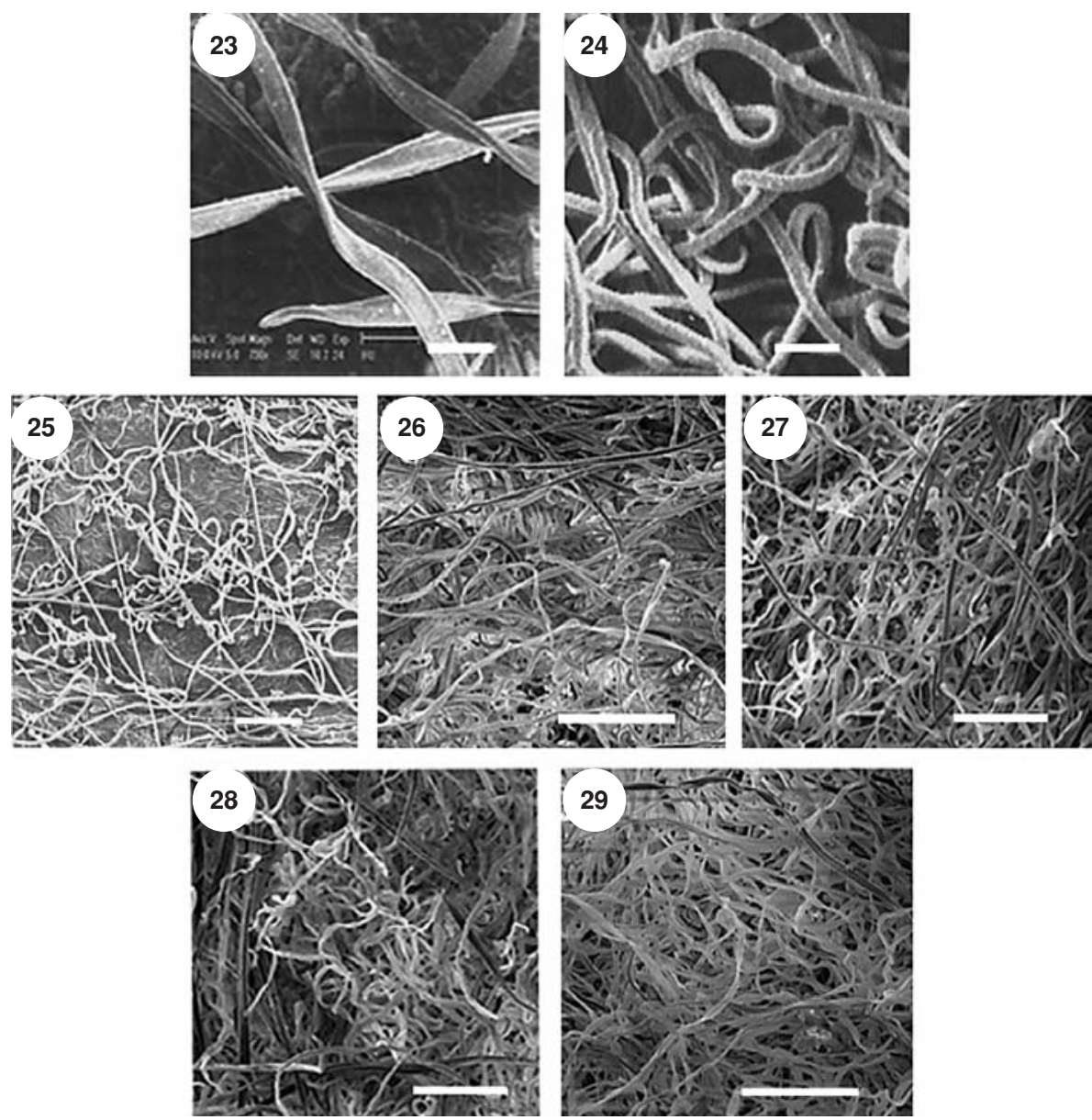

Figs 23-29. Type class III, Floccose crispate indumentum, Fig. 23 and 24. Floccose and crispate indumentum of Potentilla argentea; Fig. 25. Potentilla anserina; Fig. 26. Potentilla argentea; Fig. 27. Potentilla hololeuca; Fig. 28. Potentilla polyschista; Fig. 29. Potentilla speciosa.

Figs 23 and $24-$ scale bar $=20 \mu \mathrm{m}$; Figs 25 -29 - scale bar $=100 \mu \mathrm{m}$. 

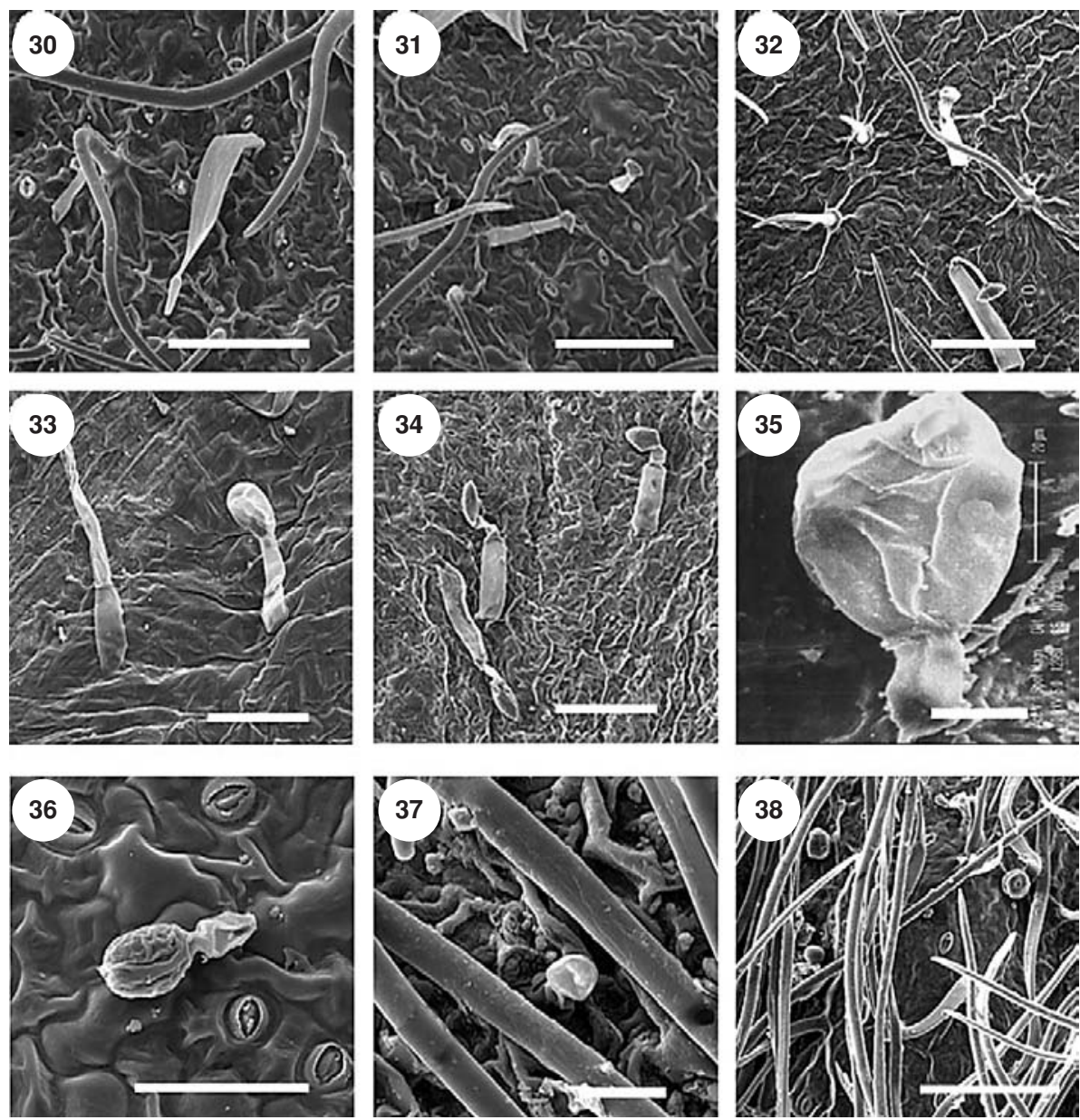

Figs 30-38. Glandular trichomes: Figs 30-32. Drymocallis poteriifolia; Figs 33 and 34. Drymocallis rupestris; Fig. 35. Potentilla aucheriana; Fig. 36. Potentilla recta; Fig. 37. Potentilla micrantha; Fig. 38. Potentilla bungei.

Fig. $35-$ scale bar $=20 \mu \mathrm{m}$; Figs $30-34$ and $36-38$ scale bar $=100 \mu \mathrm{m}$.
Schiman-Czeika, $P$. pedata Nestl. and $P$. recta L. (Figs 10 and 11) (Schiman-Czeika 1969).

The present survey shows that indumentum types carry important systematic information and form good key characters for identification purposes.

\section{LITERATURE CITED}

ADAMS J.L., BATTJES C.J., BUTHALA D.A. 1987. Biological specimen preparation for SEM by a method other than critical point drying. Proceedings of the 45th Annual Meeting of the Electron Microscopy Society of America. (Ed. by G.W. Bailey). San Francisco Press, San Francisco.

ERIKSEN B., YURTSEV B.A. 1999. Hair types in Potentilla sect. Niveae (Rosaceae) and related taxa, terminology and systematic distribution. Norske Vidensk.-Akad. Mat.-Naturvidensk. K1., Skrifter, Ny Serie. 38: 201-221.

ERTTER B., ATTAR F. 2007. Changes to Potentilla s.1. (Rosaceae) in "Flora Iranica". Rostaniha 7, Suppl. 2: 299-314.

ERTTER B. 2007. Generic realignments in tribe Potentilleae and revision of Drymocallis (Rosoideae: Rosaceae) in North America. J. Bot. Res. Inst. Texas 1: 31-46.

JUZEPCZUK S. 1941. Rosoideae. Fl. URSS. 10: 1-508.

KURTTO A., ERIKSSON T. 2003. Atlas Florae Europaeae notes. 15, Generic delimitations and nomenclatural adjustments in Potentilleae. Ann. Bot. Fennici 40: 135-141.
KHATAMSAZ M. 1993. Flora of Iran. No. 6. Rosaceae, Research Inst. of forests and rangeland, pp. 88-140.

LI C.L., IKEDA H., OHBA H. 2003. Potentilla, Comarum, Sibbaldia, Chamaerhodos, Fragaria, Duchesnea. Fl. China. 9: 291-338.

NATION J.L. 1983. A new method using hexamethyldisilazane for preparation of soft insect tissues for scanning electron microscopy. Stain Technology. 58: 347-351.

RADFORD A.E., DICKISON W.C. MASSEY J.R., BELL C.R. 1974. Vascular Plant Systematics. Harper and Row, New York.

SCHIMAN-CZEIKA H. 1969. Potentilla (Rosaceae). Flora Iranica (ed. K.H. Rechinger) 66/30.4: 78-114.

SLÍŽOVÁ D., KRS O., POSPÍŠILOVÁ B. 2003. Alternative method of rapid drying vascular specimens for scanning electron microscopy. J. Endovasc. Ther. 10: 28-287.

SOJÁK J. 1986. Notes on Potentilla. I. Hybridogenous species derived from intersectional hybrids of P. Sect. Niveae X P. Sect. Multifidae. Bot. Jahrb. Syst. 106: 145-210.

SOJÁK J. 1989. Notes on Potentilla (Rosaceae). VIII. P. nivea L. agg. Candollea 44: 741-762.

SOJÂK J. 2004. Potentilla L. (Rosaceae) and related genera in the former USSR (identification key, checklist and figures). Notes on Potentilla XVI. Bot. Jahrb. Syst. 125: 253-340.

SOJÁK J. 2007. Potentilla (Rosaceae) in China. Notes on Potentilla XIX. Harvard Pap. Bot. 12: 285-324.

STEARN W.T. 1983. Botanical Latin, 3rd ed. David and Charles, London. 
APPENDIX 1

IRAN: Province, Collector, Date

Guilan, Asalem-KhalKhal road, Faghir, 6.6.2006

Tehran,Tehran-Shemshak road, Ghahreman \& Mozaffarian, 20.7.88

Mazandaran, Firooskooh, Attar, 12.6.2006

Fars, Abadeh, Termeh \& Izadyar, 7.6.1969

Guilan, Asalem-KhalKhal road, Termeh \& Mousavi, 19.5.74

Mazandaran, Firooskooh, Attar, 27. 6.2005

Mazandaran, Kelardasht, Termeh \& mousavi, 13.8.72

Mazandaran, Kelardasht, Takhtsoliman Termeh \& mousavi, 13.8.72

Guilan,Siyahkal, Faghir, 16.6.06

Guilan,Siyahkal, Faghir, 16.6.06

Guilan, Siyahkal, Spili, Larikhani, Saidi, 13.5.93

Mazandaran, Ramsar,Samamous monts., Faghir, 22.7.06

Tehran,Gachsar,Dizin Ghahreman \& Mozaffarian, 4.8.88

Guilan, Damash-Jirandeh, Faghir, 16.6.2006

Guilan, Siyahkal, Faghir, 16.6.2006

Mazandaran, Chlous road, Faghir, 16.7.2006

Guilan, Asalem-KhalKhal road, Faghir, 16.6.06

Azarbaijan, Kalibar, Attar \& Dadjou, 17.7.93

Guilan, Damash-Jirandeh, Faghir, 16.6.06

Guilan, Damash-Jirandeh, Faghir, 16.6.2006

Qazvin, Alamout Ghahreman \& Mozaffarian, 11.8.91

Kordestan, Marivnan-Paveh, Maroufi, 21.3.2003

Fars, Abadeh,Termeh, 5.7.79

Tehran, Gachsar, Dizin, Ghahreman \& Mozaffarian, 4.8.88,

Lorestan, Khoramabad, Attar \& Mirtj, 27.7.88

Kordestan, Sanandaj, Hanagalanvillage, Maroufi, 1.6.2007

Hamedan,Alvand southern slope, Mozaffarian, 8.7.88

Kordestan, Sanandaj, Maroufi \& Kargar, 10.6.2007

Yazd, Chenaran, Ardakan-Hezarmasjed, Termeh, 1, 8.8.77

Mazandaran, Kelardasht, Khoramdasht, Faghir, 12.8.2006

Ardabil, Sabalan monts., Termeh, 15.7.71

Mazandaran, Ramsar,Samamous monts., Faghir, 22.7.2006

Guilan, Siyahkal, Faghir, 16.6.2006

Azarbaijan, Ormiyeh,Ghahreman \& Mozaffarian, 29.6.97

Guilan, Asalem-Khalkal, Faghir, 6.6.06
Accession No.

$36600(\mathrm{TUH})$

$6212(\mathrm{TUH})$

39000 (TUH)

36855 (IRAN)

36839 (IRAN)

39001 (TUH)

36854 (IRAN)

36806 (IRAN)

36586 (TUH)

36585 (TUH)

33466 (TUH)

36631 (TUH)

6987 (TUH)

36598 (TUH)

36588 (TUH)

36627 (TUH)

36605 (TUH)

17184 (TUH)

36593 (TUH)

36594 (TUH)

9963 (TUH)

6494 (TUH)

36763 (IRAN)

6985 (TUH)

24898 (TUH)

8060

64940 (TUH)

8128

36827 (IRAN)

36630 (TUH)

36761 (IRAN)

36632 (TUH)

36639 (TUH)

20056 (TUH)

36602 (TUH)

35. P. micrantha Ramond ex DC. 